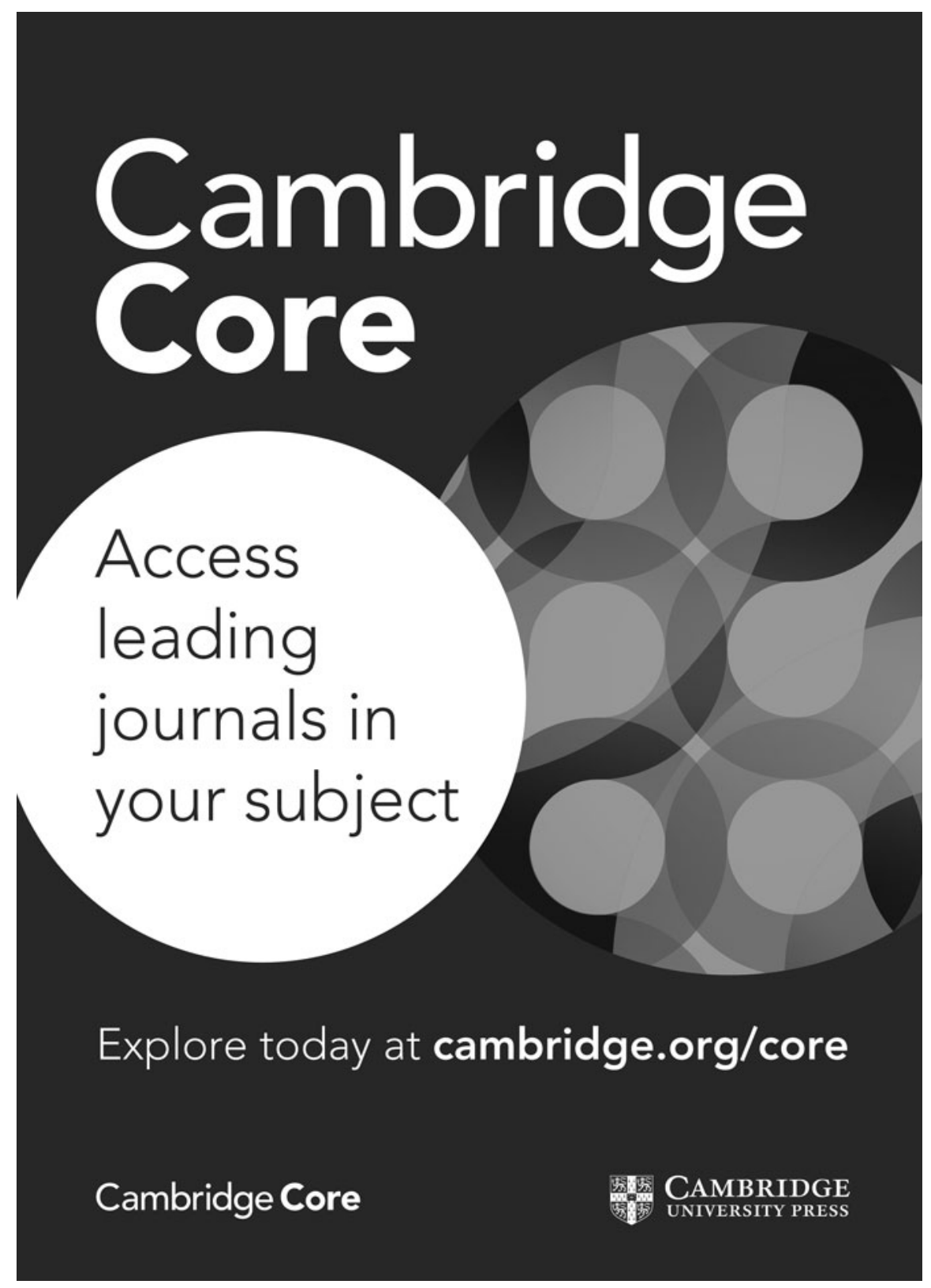




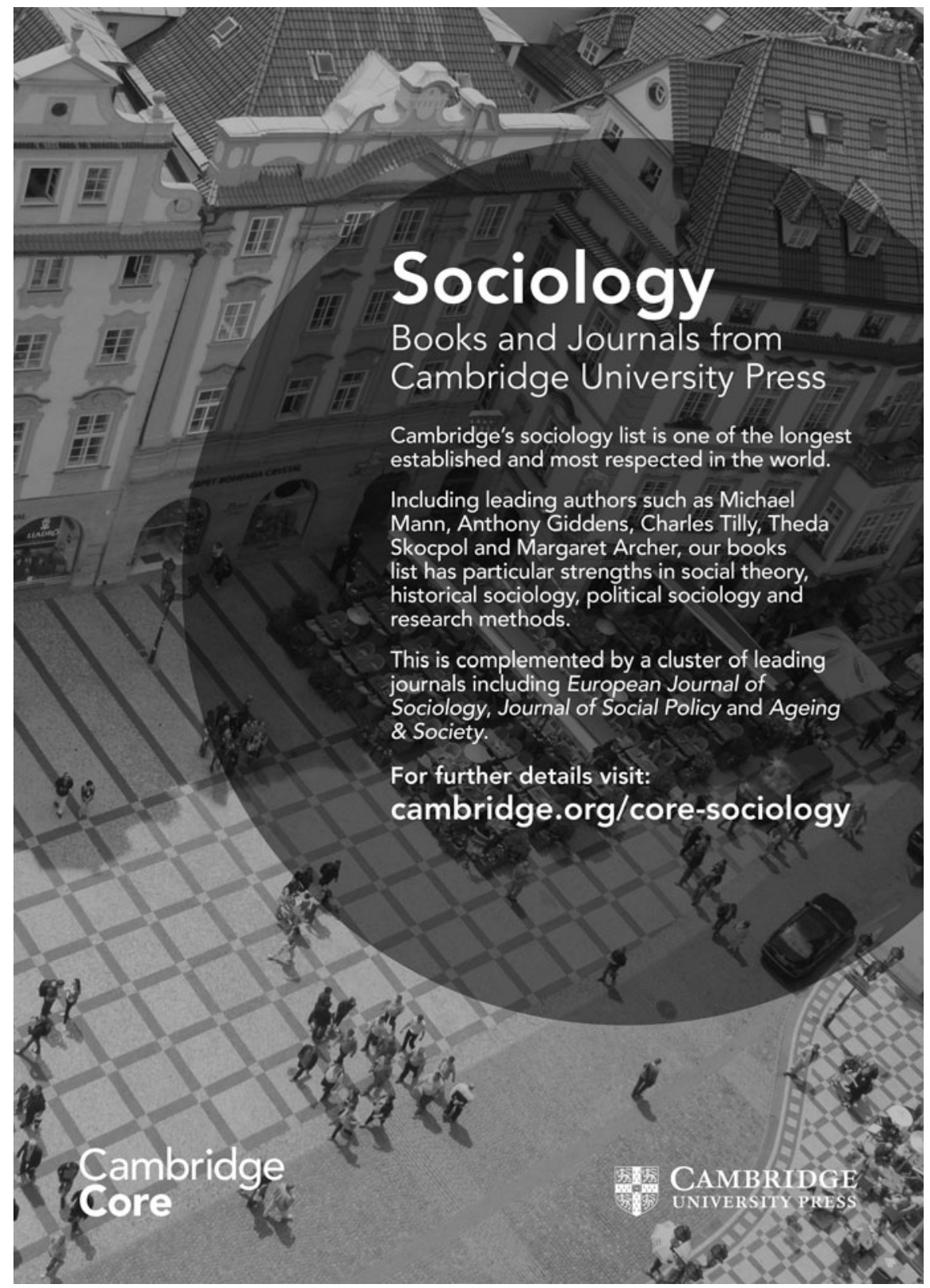




\section{Instructions for contributors}

All papers must be submitted using Manuscript Central through the journal's website at: cambridge.org/aso

\section{Submission requirements}

Submission of an article is taken to imply that it has not been published elsewhere. Authors will be required to confirm on submission of their article that the manuscript has been submitted solely to this journal and is not published, in press, or submitted elsewhere.

Papers with more than one author must designate a corresponding author. The corresponding author must confirm that co-authors have read the paper and agree to its submission.

The corresponding author should prepare (a) a complete text and (b) complete text minus the title page, acknowledgements, and any running headers of author names, to allow blinded review.

Where the paper reports original research on human subjects, confirmation must be given that ethical guidelines have been met, including adherence to the legal requirements of the study country. Authors must state the full name of the body providing the favourable ethical review and reference number.

A declaration of sources of funding must be provided if appropriate. Authors must specify what role, if any, their financial sponsors played in the design, execution, analysis and interpretation of data, or writing of the study.

Contributors of articles or reviews accepted for publication will be asked to assign copyright, on certain conditions, to Cambridge University Press. The Publisher reserves the right to typeset material by conventional means.

\section{Preparation of manuscripts}

Authors are requested to bear in mind the multi-disciplinary and international readership of the journal when writing their contribution. Care must be taken to draw out the implications of the analysis for readers in other fields, other countries, and other disciplines.

The stereotypical presentation of individuals or social groupings, including the use of ageist language, must be avoided.

Articles must be between 3,000 and 9,000 words (excluding the abstract and references). All contributions (including reviews) should be typed double-spaced with at least one-inch or two centimetre margins throughout (including notes and the list of references).

Most research articles usually have the following sections in sequence: Title page, Abstract (200-300 words), Keywords (three to eight), Main text, Statement of ethical approval as appropriate, Statement of funding, Declaration of contribution of authors, Statement of conflict of interest, Acknowledgements, Notes, References, Correspondence address for lead author. The tables and figures should be presented one to a page in sequence at the end of the paper.

The title page should give the title of the article and the author(s)' names, affiliations and postal and email addresses.

Authors are asked to follow the current style conventions as closely as possible. Please consult a very recent issue of the journal and download the full instructions for contributors from the journal's website: cambridge.org/aso

\section{Proofs and offprints}

Proofs will be sent to the corresponding author as a PDF via email for final proof reading. The proofs should be checked and any corrections returned within 2 days of receipt. The publisher reserves the right to charge authors for excessive correction of non-typographical errors.

Authors will receive a PDF of the published paper and a copy of the journal, to go to the corresponding author. If offprints are required, these must be purchased at proof stage.

Copying: This journal is registered with the Copyright Clearance Center, 222 Rosewood Drive, Danvers, MA 01923, USA. Organisations in the USA that are also registered with C.C.C. may therefore copy material (beyond the limits permitted by sections 107 and 108 of US copyright law) subject to payment to C.C.C. of the per-copy fee of $\$ 12$. This consent does not extend to multiple copying for promotional or commercial purposes. Code 0144-686X/2020 \$12.

ISI Tear Sheet Service, 3501 Market Street, Philadelphia, Pennsylvania 19104, USA, is authorised to supply single copies of separate articles for private use only.

Organisations authorised by the Copyright Licensing Agency may also copy material subject to the usual conditions. For all other use, permission should be sought from Cambridge or the American Branch of Cambridge University Press.

Internet Access: This journal is included in the Cambridge Journals Online service which can be found at cambridge.org/aso

Printed in Great Britain by Bell \& Bain Ltd, Glasgow. 
VOLUME 40 PART 5 MAY 2020

\section{CONTENTS}

Articles

925 NADIYA KELLE: Combining employment and care-giving: how differing care intensities influence employment patterns among middle-aged women in Germany

944 LORNA MCWILLIAMS, CAROLINE SWARBRICK, JANELLE YORKE,

LORRAINE BURGESS, CAROLE FARRELL, GUNN GRANDE,

SARAH BELLHOUSE and JOHN KEADY: Bridging the divide: the adjustment and decision-making experiences of people with dementia living with a recent diagnosis of cancer and its impact on family carers

966 HENRIETTA TRIP, LISA WHITEHEAD and MARIE CROWE: Perceptions of ageing and future aspirations by people with intellectual disability: a grounded theory study using photo-elicitation

984 TRISH HAFFORD-LETCHFIELD, HELEN GLEESON, PETER RYAN, BARBARA BILLINGS, RUTH TEACHER, MATTHEW QUAIFE, ANN FLYNN, STEFANO ZANONE POMA and SILVIA VICENTINI: 'He just gave up': an exploratory study into the perspectives of paid carers on supporting older people living in care homes with depression, self-harm, and suicide ideation and behaviours

1004 HILARY LAPSLEY, NGAIRE KERSE, SIMON A. MOYES, SALLY KEELING, MARAMA LEIGH MURU-LANNING, JANINE WILES and SANTOSH JATRANA: Do household living arrangements explain gender and ethnicity differences in receipt of support services? Findings from LiLACS NZ Māori and non-Māori advanced age cohorts

1021 NICOLE LAMB and GERHARD HOFFSTAEDTER: 'We walk, we laugh, we dance': refugee experiences of older Chin women in Kuala Lumpur

1039 ELYSE A. JENNINGS, NOLWAZI MKHWANAZI and LISA BERKMAN: Receipt of emotional support among rural South African adults

1064 KATIA ATTUYER, ROSE GILROY and KAREN CROUCHER: Establishing long-term research relationships with older people: exploring care practices in longitudinal studies

1084 JUDITH KASCHOWITZ: Health of migrant care-givers across Europe: what is the role of origin and welfare state context?

1106 PER H. JENSEN, KRISTIAN KONGSHØJ and WOUTER DE TAVERNIER: On how the nature of early retirement is related to post-retirement life conditions from a citizenship perspective

1130 YIN MEI NG, CHERYL TILSE and JILL WILSON: Lifecourse and housing careers of childless and poor older Malaysians

Reviews

1151 MARIA CARINNES, P. ALEJANDRIA-GONZALEZ, SUBHARATI GHOSH and NICOLAS SACCO, Aging in Global South: Challenges and Opportunities (Francisca Ortiz)

1152 NICK HUBBLE, JENNIE TAYLOR and PHILIP TEW (eds), Growing Old with the Welfare State. Eight British Lives (Pat Thane)

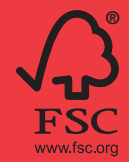

MIX

Paper from responsible sources FSC $^{\oplus}$ C007785
CAMBRIDGE UNIVERSITY PRESS 